\title{
A translatable subunit nanovaccine for COVID-19
}

Lixin Liu ${ }^{1}$, Zhijia Liu ${ }^{1}$, Haolin Chen ${ }^{1}$, Hong Liu ${ }^{1}$, Qiang $\mathrm{Gao}^{2}$, Feng Cong ${ }^{4}$, Guangxia $\mathrm{Gao}^{3}$, Yongming Chen ${ }^{1, *}$

1. School of Materials Science and Engineering, Key Laboratory for Polymeric Composite and Functional Materials of Ministry of Education, Sun Yat-sen University, Guangzhou 510275, China

2. Sinovac Biotech Co. Ltd, No. 39 Shangdi Xi Road, Beijing 100085, China

3. CAS Key Laboratory of Infection and Immunity, Institute of Biophysics, Chinese Academy of Sciences, Beijing 100101, China

4. Guangdong Laboratory Animal Monitoring Institute and Guangdong Key Laboratory of Laboratory Animals, Guangzhou 510633, China

Corresponding authors: YC (Email: chenym35@mail.sysu.edu.cn).

Lixin Liu, Zhijia Liu, and Haolin Chen contributed equally to the work.

\begin{abstract}
In order to combat severe acute respiratory syndrome coronavirus 2 (SARS-CoV-2) pandemic in the world, we formulate S1 subunit of the virus with two types of adjuvants, amphiphilic adjuvant monophosphoryl lipid A (MPLA) for Toll-like receptor 4 (TLR4) and CpG ODN for TLR9, into cationic multifunctional liposomes to produce a potent, safer, and translatable nanovaccine. The results show that the nanovaccine can efficiently elicit humoral immune response in mice. The sera from the vaccinated mice significantly inhibit SARS-CoV-2 to infect Vero cells. Moreover, relatively to the free $\mathrm{S} 1$ with traditional Alum adjuvant, the nanovaccine can elicit strong $\mathrm{T}$ cell immunity by activating both CD4+ and CD8+ cells, which may play critical roles in eliminating viral load in patients. Most importantly, the nanovaccine can elicit strong IgA antibody, providing potential mucosal protection to host. Altogether, this study offers a translatable design for a potent subunit SARS-CoV-2 nanovaccine.
\end{abstract}

Keywords: COVID-19; Cellular immunity; Humoral immunity; Liposome; SARSCoV-2; Subunit vaccine. 


\section{Introduction}

The new emergence severe acute respiratory syndrome coronavirus 2 (SARSCoV-2) causes pandemic in the worldwide. Until May 12, 2020, the number of coronavirus induced disease (COVID-19) cases is over 4 million cases and COVID19 causes over 280 thousand deaths. It is still increased rapidly and it is obviously that the outbreak of SARS-CoV-2 could not be stopped unless effective vaccines can be developed. Great efforts are paying to develop vaccines to against SARS-CoV-2 worldwide [1].

Here, we develop an adjuvanted nanovaccine with recombinant S1 subunit from SARS-CoV-2. It shows remarkable immunogenicity in mice and the serum of the vaccinated mice efficiently blocks virus infection of the cells. S1 subunit is one component of SARS-CoV-2 transmembrane spike (S) glycoprotein, a homotrimer protruding from the viral surface [2]. Its function is to bind the host receptor, angiotensin-converting enzyme 2 (ACE2), and then to trigger S2 subunit of S protein to fuse viral membrane and host cell membrane $[3,4]$.

Among different types of vaccines, subunit vaccine is very attractive because it is safer and easier to produce. However, the subunit vaccines show weak immune response in vivo due to its poor pharmacokinetics, easy degradation and lack of other components of the whole virus, which act as pathogen-associated molecular pattern (PAMP) to initiate immune response [5]. To overcome the drawbacks of subunit vaccine, researchers have developed several strategies to enhance subunit antigen immunogenicity including applying of nanotechnology for co-delivering antigen and molecular adjuvant [6]. Different types of carriers, such as synthetic polymers, chitosan, and liposomes, have been applied in formulation of nanovaccines loading with subunit antigens and adjuvants for preclinical studies [7, 8]. Here, we applied cationic liposomes as a delivering vehicle [9], in which CpG ODN for TLR9 was loaded in its internal water depot, monophosphoryl lipid A (MPLA) for TLR4 was coassembled with lipid molecules, and the anionic $\mathrm{S} 1$ at neutral $\mathrm{pH}$ was adsorbed onto its cationic surface. Thus, a potent subunit vaccine anti-SARS-CoV-2 was easily produced. This vaccine can efficiently elicit humoral immune response in mice, the 
sera from the vaccinated mice can significantly inhibit the virus infection to Vero cells. More importantly, strong T cell immunity is also elicited and both CD4+ and CD8+ cells are more strongly activated than the control. In addition, a higher amount of S1- specific IgA antibody can be detected in the nanovaccine immunized group. All the characters of the present nanovaccine show unique advantage in protecting host against SARS-CoV-2. Since the delivery materials have been approved by FDA and two adjuvants are under preclinical trials, the vaccine shows high technological translation for application.

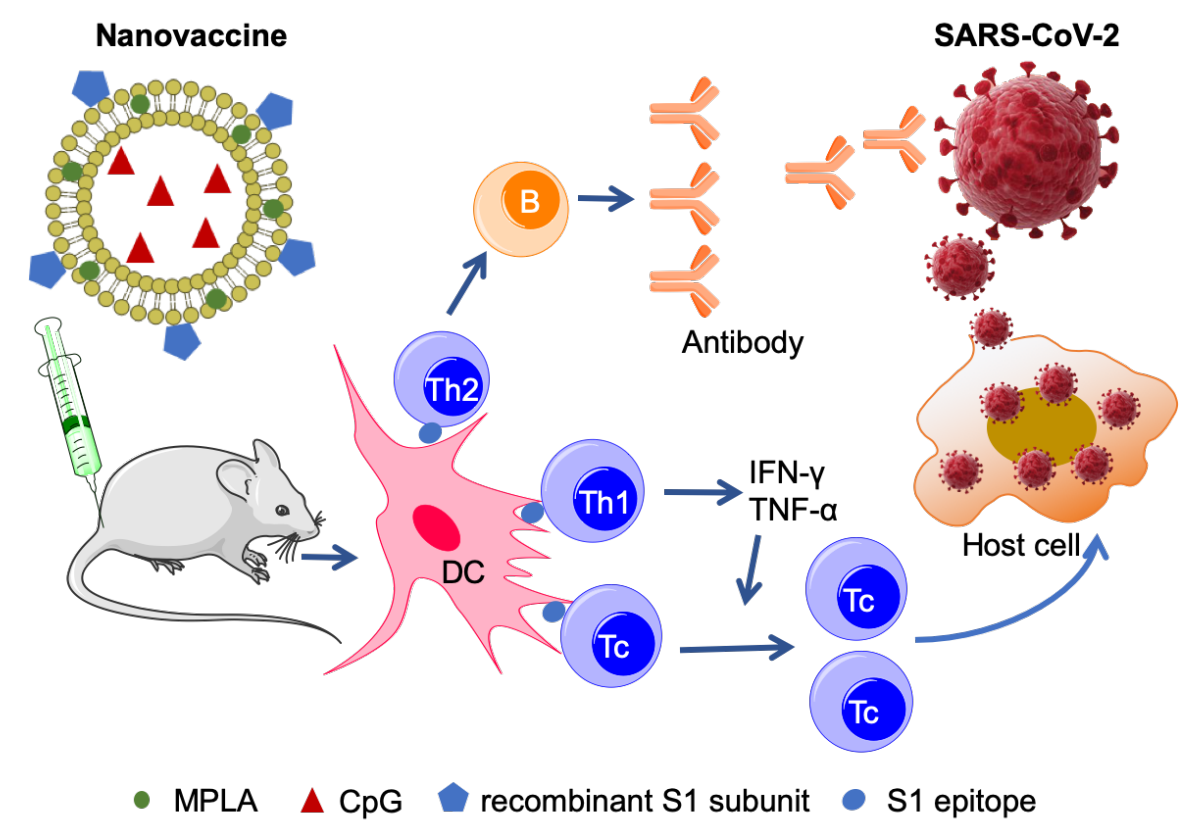

Fig. 1. Schematic of liposomal subunit nanovaccine for anti-SARS-CoV-2.

\section{Results}

\section{Characterization of adjuvant-loaded liposome and vaccine}

MPLA/CpG-loaded liposome particle, $\mathrm{p}(\mathrm{M}+\mathrm{C})$, was produced via a thin film hydration approach by using cationic 1, 2-dioleoyl-3-trimethylammonium-propane (DOTAP), helper lipid 1, 2-dioleoyl-sn-glycero-3-phosphoethanolamine (DOPE), and cholesterol as carrier materials. Charge interaction has been commonly applied to load the proteins and nucleic acids onto surface of particles [10-12] and thus we applied this facile method to generate vaccines. $\mathrm{p}(\mathrm{M}+\mathrm{C})-\mathrm{S} 1$ vaccine was formed through mixing of $\mathrm{p}(\mathrm{M}+\mathrm{C})$ with a solution of S1. As shown in Fig. $\mathbf{2 A}$ and $\mathbf{2 B}$, the results of 
dynamic light scattering showed that an average particle diameter was about $135 \mathrm{~nm}$ for $\mathrm{p}(\mathrm{M}+\mathrm{C})$ and then changed to $158 \mathrm{~nm}$ for $\mathrm{p}(\mathrm{M}+\mathrm{C})-\mathrm{S} 1$. Compared to the surface charges of $\mathrm{p}(\mathrm{M}+\mathrm{C})(+48.1 \mathrm{mV}), \zeta$-potential of $\mathrm{p}(\mathrm{M}+\mathrm{C})-\mathrm{S} 1$ was decreased to +30.4 $\mathrm{mV}$ (Fig. 2C) due to the charge neutralization. These results suggested that S1 was absorbed onto the surface of $\mathrm{p}(\mathrm{M}+\mathrm{C})$ and nanoparticulate vaccine was formulated. Such obtained $\mathrm{p}(\mathrm{M}+\mathrm{C})$ and $\mathrm{p}(\mathrm{M}+\mathrm{C})-\mathrm{S} 1$ exhibited high colloidal stability after 11week storage in $4{ }^{\circ} \mathrm{C}$ (Fig. 2D and 2E).

A

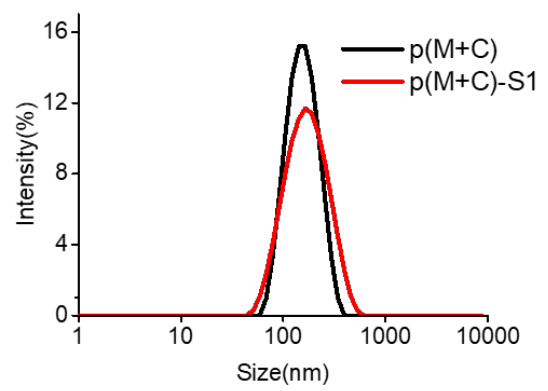

D

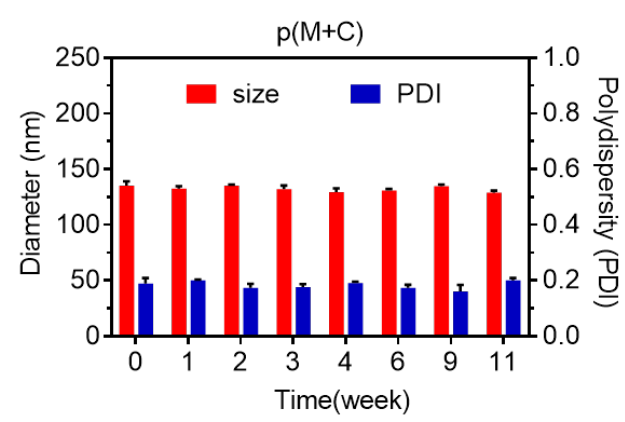

B

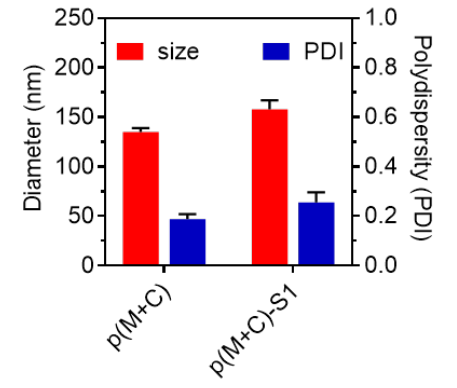

C

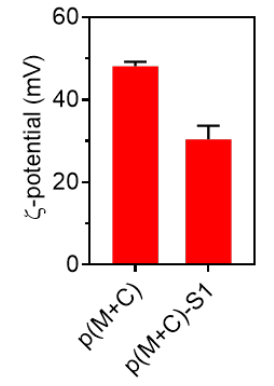

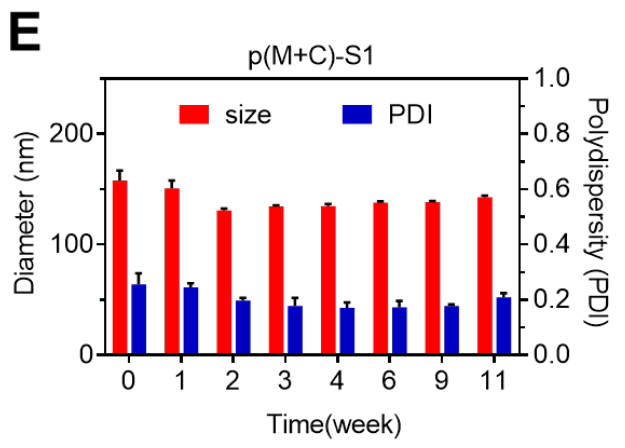

Fig. 2. (A) Dynamic light scattering profiles of $p(M+C)$ and $p(M+C)-S 1$. (B) Z-average diameter, PDI and $(\mathbf{C}) \zeta$-potential of $\mathrm{p}(\mathrm{M}+\mathrm{C})$ and $\mathrm{p}(\mathrm{M}+\mathrm{C})-\mathrm{S} 1$. Storage stability of $(\mathbf{D})$ $\mathrm{p}(\mathrm{M}+\mathrm{C})$ and $(\mathbf{E}) \mathrm{p}(\mathrm{M}+\mathrm{C})-\mathrm{S} 1$ in $4^{\circ} \mathrm{C}$ conditions.

\section{Nanovaccine elicitation of robust S1-specific antibody production in vivo}

Humoral immunity is important to protect people from virus infection[13] and the S1-specific antibody was evaluated in this study. BALB/c mice were immunized three times on day 0,14 , and 28 with different vaccine formulations, Alum + free S1 $(\mathrm{A}+\mathrm{S} 1)$, free MPLA + free $\mathrm{CpG}+$ free $\mathrm{S} 1(\mathrm{f}(\mathrm{M}+\mathrm{C}+\mathrm{S} 1))$, and $\mathrm{p}(\mathrm{M}+\mathrm{C})-\mathrm{S} 1$, with untreated as control (Fig. 3A). As shown in Fig. 3B-3C, p(M+C)-S1 stimulated a high level of antibody titer of total IgG, IgG1 and IgG2a compared with the A+S1 and 
$\mathrm{f}(\mathrm{M}+\mathrm{C}+\mathrm{S} 1)$. Especially, $\mathrm{IgG} 2 \mathrm{a}$ of $\mathrm{p}(\mathrm{M}+\mathrm{C})-\mathrm{S} 1$ and $\mathrm{f}(\mathrm{M}+\mathrm{C}+\mathrm{S} 1)$ treated groups were much higher than that of $\mathrm{A}+\mathrm{S} 1$ group at day 28, day 42, and day 65. At day 14 after the first vaccination, the ratios of $\operatorname{IgG} 2 \mathrm{a} / \mathrm{IgG} 1$ of $\mathrm{p}(\mathrm{M}+\mathrm{C})-\mathrm{S} 1$ and $\mathrm{f}(\mathrm{M}+\mathrm{C}+\mathrm{S} 1)$, capacity of polarization of $\mathrm{T}$ helper cells towards a dominant Th1 response, are 0.88 and 0.79 , respectively, larger than that of $\mathrm{A}+\mathrm{S} 1(0.50)$. Then, the ratio of $\operatorname{IgG} 2 \mathrm{a} / \mathrm{IgG} 1$ in all the groups decreased from day 14 to day 28 , whereas, A+S1 group decreased more significantly. After third immunization, the ratio of $\operatorname{IgG} 2 \mathrm{a} / \mathrm{IgG} 1$ of $\mathrm{p}(\mathrm{M}+\mathrm{C})-\mathrm{S} 1$ and $\mathrm{f}(\mathrm{M}+\mathrm{C}+\mathrm{S} 1)$ groups increased again and kept up to day 65 . One the contrary, the ratio of $\mathrm{A}+\mathrm{S} 1$ group further decreased to 0.06 at day 42 and lasted day 65. Altogether, MPLA and CpG adjuvanted vaccine could polarize the Thelper cells to Th1 dominant immunity and the particulate vaccine in liposome could be more efficient than the free one, evoking more efficient cell immunity. Conversely, traditional Alum adjuvant stimulated a Th2-dominant response. Additionally, the humoral immunity elicited by particulate vaccine was higher than the other two groups. From nasopharynx mucus eluted from the mice, we found that $\mathrm{p}(\mathrm{M}+\mathrm{C})-\mathrm{S} 1$ immunized mice produced higher amount of S1-specific IgA than other groups (Fig. 3D). Therefore, p(M+C)-S1 nanovaccine could elicit both stronger humoral, cellular and mucus immunity than that of Alum adjuvant group, which showed high potency to be further developed. 

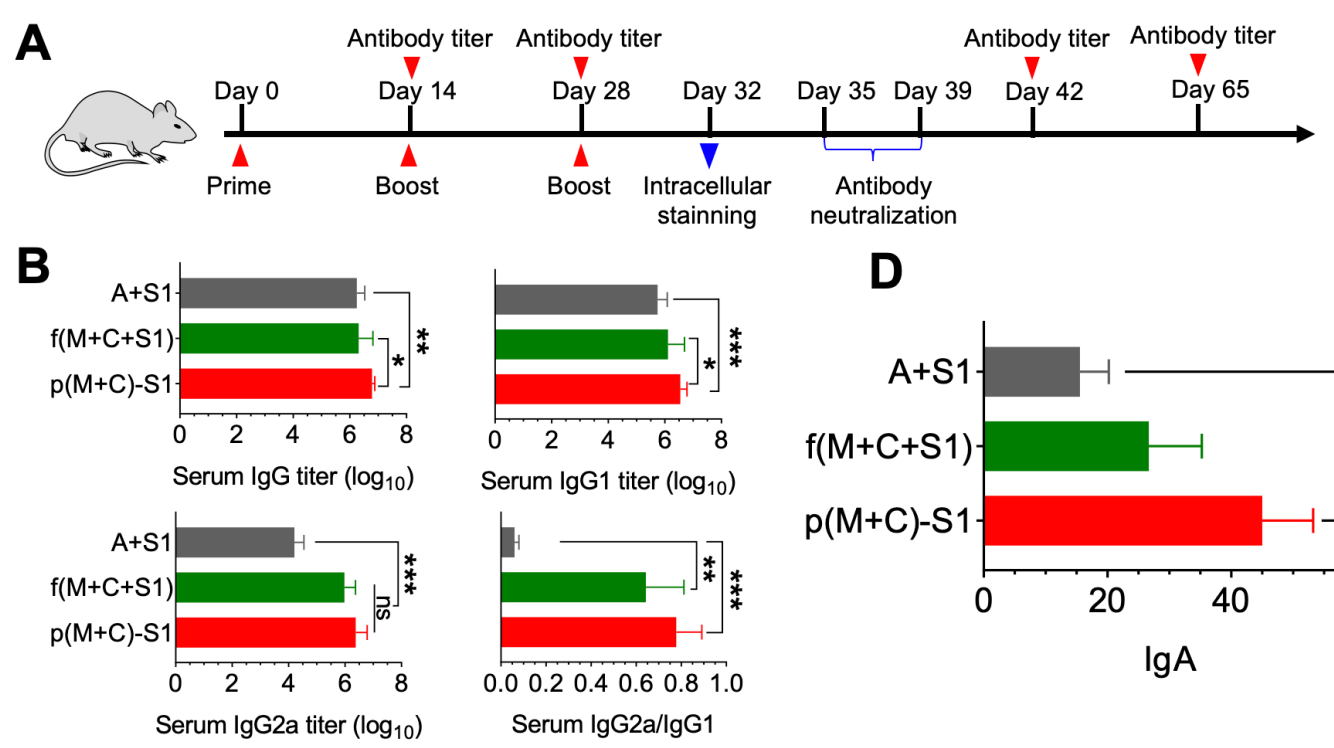

D
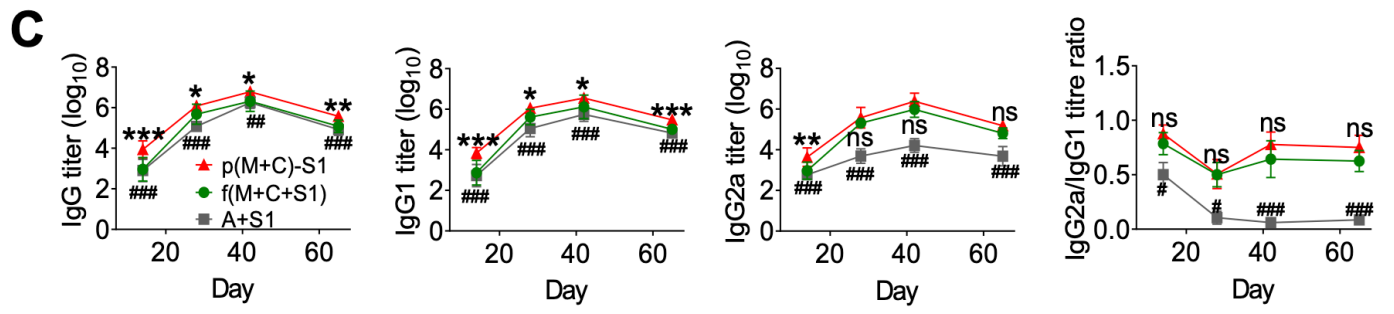

Fig. 3. Nanovaccines elicit strong humoral immunity. (A) Schematic of the immunization strategy. (B) Quantitative comparison of S1-specific production of IgG, IgG1, IgG2a and IgG2a/IgG1 on day 42. (C) Change of antibody titer over time (* represents comparison of $\mathrm{p}(\mathrm{M}+\mathrm{C})-\mathrm{S} 1$ with $\mathrm{f}(\mathrm{M}+\mathrm{C}+\mathrm{S} 1)$, \# represents comparison of $\mathrm{p}(\mathrm{M}+\mathrm{C})-\mathrm{S} 1$ with $\mathrm{A}+\mathrm{S} 1), \mathrm{n}=10$. (D) Quantitative comparison of S1-specific production of $\operatorname{IgA}$ at day 65 . Data are presented as the mean $\pm \operatorname{SEM}\left({ }^{*} P\right.$ or ${ }^{\#} P<0.05$, ${ }^{* *} P$ or ${ }^{\# \#} P<0.01,{ }^{* * *} P$ or $\left.{ }^{\# \#} P<0.001\right)$.

As reported previously, the antibodies in sera of the recovered patients of SARS were disappeared after one year[14, 15]. Whereas, the T cells were persistent in the patients for up to 6 to 11 years[16, 17], which indicated that cell immunity should be considered in the SARS-CoV-2 vaccine. Here, to investigate whether nanovaccine can activate T cells, the intracellular staining of IFN- $\gamma$ and TNF- $\alpha$ of T cells was conducted. As shown in Fig. 4A-4D, the mice injected with p(M+C)-S1 elicited a significantly higher frequency of IFN- $\gamma$ or TNF- $\alpha$ producing $\mathrm{CD}^{+} \mathrm{T}$ cells $(1.92 \%$, 
$0.74 \%)$ and $\mathrm{CD} 8 \alpha^{+}(1.21 \%, 1.64 \%)$ than the mice treated with $\mathrm{A}+\mathrm{S} 1$ producing $\mathrm{CD} 4^{+}$ $\mathrm{T}$ cells $(0.94 \%, 0.45 \%)$ and $\mathrm{CD} 8 \alpha^{+} \mathrm{T}$ cells $(0.83 \%, 0.77 \%)$, respectively. It is noteworthy that $\mathrm{CD} 8^{+} \mathrm{T}$ cell in $\mathrm{f}(\mathrm{M}+\mathrm{C}+\mathrm{S} 1)$ was not significantly activated than the other two groups, which may be due to the antigen in a free form could not be efficiently cross-delivered by MHC I $[18,19]$. The total IFN- $\gamma$ and TNF- $\alpha$ expressed in $\mathrm{CD}^{+}$and $\mathrm{CD}^{+} \mathrm{T}$ cells of $\mathrm{p}(\mathrm{M}+\mathrm{C})-\mathrm{S} 1$ group were $2.1 \sim$ and $1.8 \sim$ folds than that in $\mathrm{A}+\mathrm{S} 1$ group (Fig. $\mathbf{4 E}$ and $\mathbf{4 F}$ ). Thus, it is further confirmed that $\mathrm{p}(\mathrm{M}+\mathrm{C})-\mathrm{S} 1$ could evoke cell immunity as well as a high humoral immunity, implying that the $\mathrm{p}(\mathrm{M}+\mathrm{C})$ $\mathrm{S} 1$ is a promising vaccine candidate for protecting the people from infection.
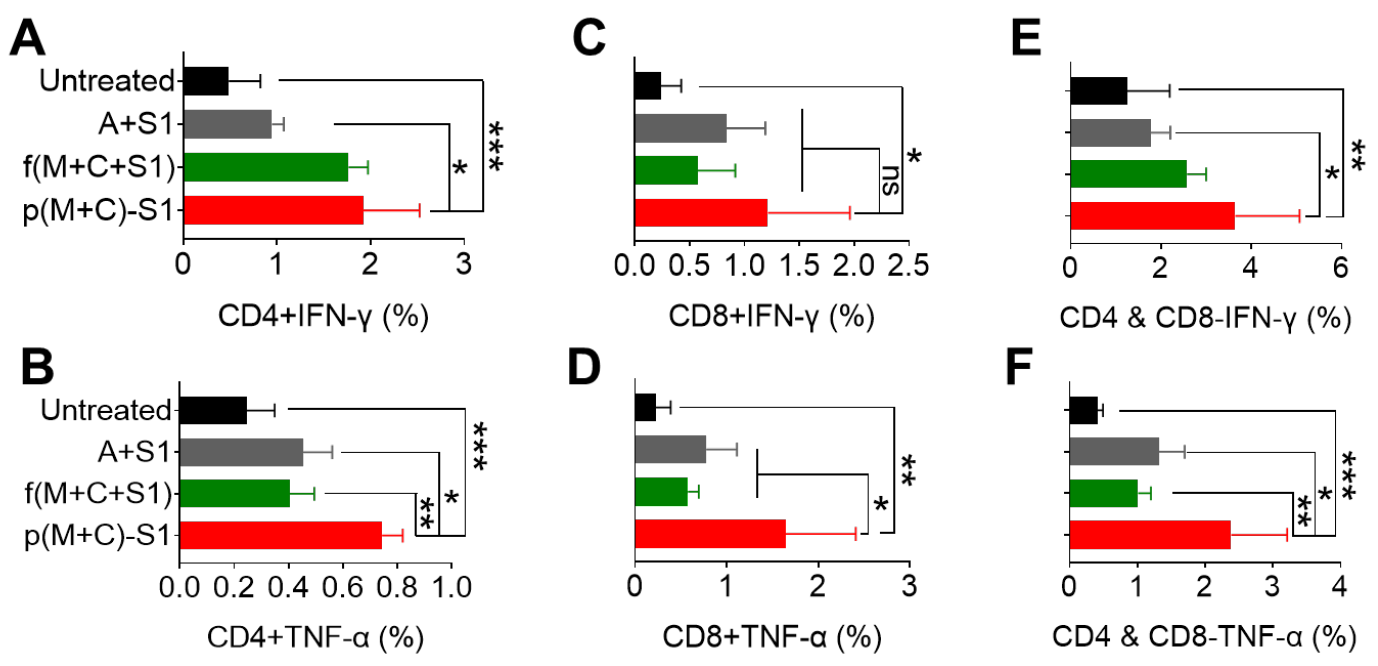

$\mathbf{F}$

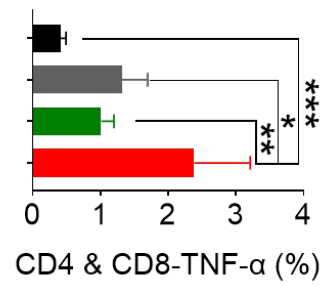

Fig. 4. Nanovaccines elicit a potent T cell response. (A, C) IFN- $\gamma$ and $(\mathbf{B}, \mathbf{D}) \mathrm{TNF}-\alpha$ expressed in $\mathrm{CD}^{+}$and $\mathrm{CD} 8^{+} \mathrm{T}$ cells in blood on day 32 after restimulation with different formulations of $\mathrm{S} 1(\mathrm{n}=10)$ by flow cytometry analysis. Total $(\mathbf{E}) \mathrm{IFN}-\gamma$ and (F) TNF- $\alpha$ expressed in $\mathrm{CD}^{+}$and $\mathrm{CD}^{+} \mathrm{T}$ cells in blood on day 32 after restimulation with different formulations of S1 $(\mathrm{n}=10)$ by flow cytometry analysis. Data are presented as the mean $\pm \operatorname{SEM}(* P<0.05, * * P<0.01, * * * P<0.001)$.

\section{COVID-19 neutralization in vitro}

Specificity of the antibody induced by vaccines is of importance. To test the neutralization ability of serum antibody from the different group, microneutralization assay was performed using SARS-CoV-2 strain CZ01 isolated from patients with Vero cells [1]. The mean neutralizing antibody titer against CZ01 strain of $\mathrm{p}(\mathrm{M}+\mathrm{C})-\mathrm{S} 1$ nanovaccine was above 1024 (>1024), which is significantly higher than control. 
Also, it is higher than that of $\mathrm{A}+\mathrm{S} 1$ group (384) and $\mathrm{f}(\mathrm{M}+\mathrm{C}+\mathrm{S} 1)$ group (768).

Effective titer of antibody in vitro indicated that the $\mathrm{p}(\mathrm{M}+\mathrm{C})-\mathrm{S} 1$ has potential for in vivo neutralization challenge and pre-clinical trial.

\section{Discussion}

Until April, 2020, over one hundred of various vaccines worldwide are under research and development. They include RNA vaccine, DNA vaccine, adenovirusbased vaccine, inactivated virus vaccine, recombinant/subunit protein vaccine, viruslike particle and peptide vaccine etc. [20]. Among them, mRNA, adenovirus-based, and inactivated virus vaccines have been quickly moved into clinical development. Also, more than 20 protein vaccines are under investigations at different stages. However, it is still hard to find research articles on subunit vaccine, let alone how the subunit antigens being delivered.

Compared with other types of vaccines, the subunit protein vaccine is safer and cheaper to produce. Previous research on vaccines using spike protein of severe acute respiratory syndrome coronavirus (SARS-CoV) as subunit showed that the antibodies could effectively prevent the coronavirus from binding to cell and membrane fusion, and neutralize the virus during infection [21]. The causative agent of ongoing pandemic SARS-CoV-2, along with SARS-CoV[22], and middle-east respiratory syndrome (MERS-CoV)[23], belongs to the genus $\beta$ coronavirus, family of Coronaviridae. The three zoonotic coronaviruses harboring liner, single-stranded positive RNA genome cause most deadly pneumonia in human. Though the S protein gene sequence of SARS-CoV-2 was less than $75 \%$ similar to the S protein sequence of SARS-CoV, the cell membrane binding receptor is still ACE2 [3, 24, 25]. Therefore, the S protein of SARS-CoV-2 still plays a major role in binding host cells and promoting membrane fusion, namely, S protein can be used as a major target for subunit vaccine preparation $[26,27]$. However, in general, the immunogenicity of free subunit antigens is weak when used alone, and it is difficult to stimulate a strong immune response. In addition to antigen, the body identifies pathogenic microorganisms by PAMP, such as TLRs for activating the innate immunity. As a result, proliferation and maturation of T cells effectively cause cellular immunity, 
Therefore, TLR agonists in vaccine are playing a key role in the clearance of intracellular pathogens [28]. However, low molecular weight molecular adjuvants can enter blood vessels and cause a systemic inflammatory response. To overcome the problems of protein antigens and adjuvants, particulate antigens and agonist adjuvants as well as delivery system are needed for a potent vaccine.

Here, we applied cationic liposome as carriers to anchor S1 subunit of the virus onto their surface by the charge interaction, to entrap $\mathrm{CpG}$ into their internal aqueous phase, and to insert MPLA along their lipid bilayer. Thus, we formulated S1 protein and TLR agonists into particulate vaccine with diameter of ca. $150 \mathrm{~nm}$. The results showed that the cell response as well as robust humoral is activated and the serum antibodies of mice could neutralize the virus efficiently. The robust immune response should be attributed to use of MPLA, as a TLR4 agonist to induce Th1 and Th2 response, and $\mathrm{CpG}$, as TLR9 agonist to strengthen a better Th1 response. Moreover, a combination of MPLA and $\mathrm{CpG}$ in $\mathrm{p}(\mathrm{M}+\mathrm{C})-\mathrm{S} 1$ nanovaccine benefits on eliciting both humoral and cell-mediated immune responses. As a contrast, the subunit with Alum only elicits humoral immunity. It has been reported that a cellular immunity plays critical roles in decreasing viral load of patients in SARS-CoV infection in 2003 [27]. More importantly, it was found that virus specific memory T cells persist up to 6 to 11 years in recovered patients[16, 17]. On the contrary, the virus-specific memory B cells lack in the patients, and the antibody disappeared after one year [29]. This indicates that the cell immunity could be perhaps much more important in the SARS-CoV-2 development. Additionally, we showed the nanovaccine could elicit stronger mucus S1-specific IgA antibody than the traditional Alum group. It is reported that SARSCoV-2 attached to goblet and ciliated cells in the nose as initial infection site to invade host and thus the mucus immunity may be important to protect people from viral infection [30].

Furthermore, it is known that liposome products for drug delivery, like Ambisome ${ }^{\circledR}$ and Doxil ${ }^{\circledR}$, are on the market and many more are in clinical trials. Thus, the present lipid-based nanovaccine with the narrow size distribution and high 
biocompatibility is safe and easy for scale-up manufacture for further application development.

In summary, we constructed a subunit antigen lipid nanovaccine for COVID-19. With aid of MPLA and CpG in adjuvants, the nanovaccine efficiently induces a robust humoral and CD8+ and CD4+ T-cell responses. Furthermore, the vaccine shows an efficient in vitro neutralization effect. Since lipid-based formulation technique has already been applied, this nanovaccine may have great potential for clinical application.

\section{Methods}

Materials. DOTAP and DOPE were purchased from A.V.T. (Shanghai) Pharmaceutical (Shanghai, China). Cholesterol was obtained from Shanghai Macklin Biochemical (Shanghai, China). Monophosphoryl lipid A (MPLA) was from Avanti Polar Lipids (Alabaster, USA). Inject ${ }^{\mathrm{TM}}$ Alum Adjuvant was purchased from Thermo Scientific (Rockford, USA). CpG ODN1826 was from InvivoGen (San Diego, USA). Recombinant SARS-CoV-2 spike protein (S1) was purchased from Sino Biological (Beijing, China). Anti-mouse CD3e-Pacific Blue ${ }^{\mathrm{TM}}$, anti-mouse IFN- $\gamma$-PE, anti-mouse TNF- $\alpha-P E / C y 7$, Zombie Violet ${ }^{\mathrm{TM}}$ Fixable Viability Kit, anti-mouse CD4-FITC were purchased form Biolegend (San Diego, USA). Anti-mouse CD8 $\alpha$-APC, anti-mouse CD3-PerCP-eFluor 710, HRP-conjugated anti-mouse IgG, IgG2a and IgG1 were purchased from Abcam (Cambridge, England).

Preparation of adjuvant-loaded liposome and vaccine. Adjuvant-loaded liposome was prepared through a lipid film hydration approach with slight modifications[31]. Briefly, DOTAP, DOPE, cholesterol and MPLA $(50 \mu \mathrm{g})$ with the weight ratio of 150: 50: 20: 1 were dissolved in $5 \mathrm{~mL}$ of ethanol and then thin lipid film was obtained after removal of organic solvent by a vacuum rotary evaporator at $45^{\circ} \mathrm{C}$. Subsequently, this lipid film was rapidly hydrated with $5 \mathrm{~mL}$ of $\mathrm{CpG}$ aqueous solution $(72.5 \mu \mathrm{g})$ and followed by five-repeated extrusion through a polycarbonate filter $(0.1 \mu \mathrm{m}$, Whatman $)$ for the preparation of MPLA/CpG-loaded liposome 
$(\mathrm{p}(\mathrm{M}+\mathrm{C}))$. Furthermore, $\mathrm{p}(\mathrm{M}+\mathrm{C})$ was formulated with $\mathrm{S} 1$ solution and then incubated at $4{ }^{\circ} \mathrm{C}$ overnight for obtaining the vaccine, $\mathrm{p}(\mathrm{M}+\mathrm{C})-\mathrm{S} 1$. Besides, particle diameter, polydispersity index (PDI), and $\zeta$-potential were characterized by a Zetasizer Nano ZS Instrument (Malvern) at room temperature.

Animal immunization. Pathogen-free female BALB/c mice (5-8 weeks, $\mathrm{n}=10$ for each group) were injected with $\mathrm{A}+\mathrm{S} 1$, Free $(\mathrm{M}+\mathrm{C}+\mathrm{S} 1)$ and $\mathrm{p}(\mathrm{M}+\mathrm{C})-\mathrm{S} 1$ at tail base subcutaneously, which containing S1 (20 $\mu \mathrm{g}$ per mouse), CpG (2.9 $\mu \mathrm{g}$ per mouse) and MPLA (2.0 $\mu \mathrm{g}$ per mouse), correspondingly. Mice untreated are served as negative control. Then the mice were boosted with the same dose at day 14 and day 28 post the first vaccination.

Antibody titer assay. $100 \mu \mathrm{L}$ of blood from groups of $\mathrm{A}+\mathrm{S} 1, \mathrm{f}(\mathrm{M}+\mathrm{C}+\mathrm{S} 1)$, and $\mathrm{p}(\mathrm{M}+\mathrm{C})-\mathrm{S} 1$ was collected from the mice eye socket vein and the serum were collected by centrifugation at $3000 \mathrm{rpm}$ for $10 \mathrm{~min}$ at room temperature. $\mathrm{S} 1$ was diluted in coating buffer (50 mM Na $\left.2 \mathrm{CO}_{3}-\mathrm{NaHCO}_{3}, \mathrm{pH} 9.6\right)$ at a concentration of $4.3 \mu \mathrm{g} / \mathrm{mL}$ and added into each well in the ELISA plates at $37^{\circ} \mathrm{C}$ for $2 \mathrm{~h}$. Subsequently, the S1 antigen was removed and washed with PBST (PBS with 0.05\% Tween-20) for one time, then the plates were blocked with $3 \% \mathrm{BSA}$ in PBST for $2 \mathrm{~h}$ at $37^{\circ} \mathrm{C}$. The plates were then washed three times with PBST. The serum samples of different groups were diluted with the corresponding folds and 2-time gradient diluted with 1\% BSA in PBS and incubated for $2 \mathrm{~h}$ at $37^{\circ} \mathrm{C}$. After that, plates were washed with PBST 4 times and then incubated with HRP-conjugated IgG, IgG1, and IgG2a at $1: 1 \times 10^{5}, 1: 5 \times 10^{4}, 1$ : $5 \times 10^{4}$ for $60 \mathrm{~min}$ at $37^{\circ} \mathrm{C}$, followed with another 4 times washing with PBST. TMB substrate was then added and incubated for $10-15 \mathrm{~min}$ in dark at $37^{\circ} \mathrm{C}$. Then, enzymatic reaction was terminated by adding $2 \mathrm{M} \mathrm{H}_{2} \mathrm{SO}_{4}$ and the plates were read with a Multimode Microplate Reader at $450 \mathrm{~nm}$. The titers were determined using a dilution factor at which the OD450 value of sample equaled to the twice of the negative control.

For IgA detection, the nasal lavage fluids and lung lavage fluids were collected on day 65 after the priming, and centrifuged with $12,000 \mathrm{rpm}$ for $10 \mathrm{~min}$ at $4{ }^{\circ} \mathrm{C}$. As 
described, the supernatant was analyzed for IgA by ELISA. A non-immunized group was used as a negative control.

Intracellular cytokines staining. The function of $\mathrm{T}$ cell in peripheral blood mononuclear cells (PBMCs) was assessed by detected the intracellular IFN- $\gamma$ and TNF- $\alpha$ expressing. After 32 days post the first immunization, $100 \mu \mathrm{L}$ of blood from groups of $\mathrm{A}+\mathrm{S} 1, \mathrm{f}(\mathrm{M}+\mathrm{C}+\mathrm{S} 1)$ and $\mathrm{p}(\mathrm{M}+\mathrm{C})-\mathrm{S} 1$ was collected from the mice eye socket vein and the leukocytes were collected by lysing the erythrocytes by ACK lysis buffer. And the intracellular staining was conducted as previously[32].

Neutralizing assay. Serum samples were inactivated at $56{ }^{\circ} \mathrm{C}$ for $0.5 \mathrm{~h}$ and serially diluted with cell culture medium in two-fold steps. The diluted serums were mixed with SARS-CoV-2 virus suspension of 100 TCID $_{50}$ in 96-well plates at a ratio of $1: 1$, followed by $2 \mathrm{~h}$ incubation at $36.5{ }^{\circ} \mathrm{C}$ in a $5 \% \mathrm{CO}_{2}$ incubator. $1-2$ $\times 10^{4}$ Vero cells were then added to the serum-virus mixture, and the plates were incubated for 5 days at $36.5^{\circ} \mathrm{C}$ in a $5 \% \mathrm{CO}_{2}$ incubator. Cytopathic effect (CPE) of each well was recorded under microscopes, and the neutralizing titer was calculated by the dilution number of $50 \%$ protective condition.

Statistical analysis. Statistical analyses were performed with One-way ANOVA using SPSS (version 19.0; SPSS, Chicago, III) software for Windows. $* P<0.05, * * P$ $<0.01$ or $* * * P<0.001$ were considered statistically significant at different level.

\section{Author contribution}

LL designed, conducted partial experiments, and wrote paper. ZL, HC and HL conducted partial experiments. QG supplied virus neutralization. GG supplied discussion. FC supplied animal support. YC supervised and wrote paper.

\section{Acknowledgement}

Financial support from the National Natural Science Foundation of China (51820105004) and the Guangdong Innovative and Entrepreneurial Research Team Program (2013S086) is gratefully acknowledged. 


\section{Data availability}

The data in this study are available within the paper and its Supplementary Information files. Source data in this study are available from the corresponding author upon reasonable request.

\section{References}

[1] Q. Gao, L. Bao, H. Mao, L. Wang, K. Xu, M. Yang, Y. Li, L. Zhu, N. Wang, Z. Lv, H. Gao, X. Ge, B. Kan, Y. Hu, J. Liu, F. Cai, D. Jiang, Y. Yin, C. Qin, J. Li, X. Gong, X. Lou, W. Shi, D. Wu, H. Zhang, L. Zhu, W. Deng, Y. Li, J. Lu, C. Li, X. Wang, W. Yin, Y. Zhang, C. Qin, Development of an inactivated vaccine candidate for SARS-CoV-2, Science (2020) eabc1932.

[2] M. Hoffmann, H. Kleine-Weber, N. Krüger, M. Müller, C. Drosten, S. Pöhlmann, The novel coronavirus 2019 (2019-nCoV) uses the SARS-coronavirus receptor ACE2 and the cellular protease TMPRSS2 for entry into target cells, bioRxiv (2020) 2020.01.31.929042.

[3] Y. Zhao, Z. Zhao, Y. Wang, Y. Zhou, Y. Ma, W. Zuo, Single-cell RNA expression profiling of ACE2, the receptor of SARS-CoV-2, bioRxiv (2020) 2020.01.26.919985.

[4] P. Zhou, X.-L. Yang, X.-G. Wang, B. Hu, L. Zhang, W. Zhang, H.-R. Si, Y. Zhu, B. Li, C.-L. Huang, H.-D. Chen, J. Chen, Y. Luo, H. Guo, R.-D. Jiang, M.-Q. Liu, Y. Chen, X.-R. Shen, X. Wang, X.-S. Zheng, K. Zhao, Q.-J. Chen, F. Deng, L.-L. Liu, B. Yan, F.-X. Zhan, Y.-Y. Wang, G. Xiao, Z.-L. Shi, Discovery of a novel coronavirus associated with the recent pneumonia outbreak in humans and its potential bat origin, bioRxiv (2020) 2020.01.22.914952.

[5] A. Vartak, S.J. Sucheck, Recent Advances in Subunit Vaccine Carriers, Vaccines 4(2) (2016) 12.

[6] Y. Fan, J.J. Moon, Particulate delivery systems for vaccination against bioterrorism agents and emerging infectious pathogens, Wiley interdisciplinary reviews. Nanomedicine and nanobiotechnology 9(1) (2017) 10.1002/wnan.1403.

[7] M.F. Bachmann, G.T. Jennings, Vaccine delivery: a matter of size, geometry, kinetics and molecular patterns, Nature Reviews Immunology 10(11) (2010) 787-796.

[8] K.T. Gause, A.K. Wheatley, J. Cui, Y. Yan, S.J. Kent, F. Caruso, Immunological Principles Guiding the Rational Design of Particles for Vaccine Delivery, Acs Nano 11(1) (2017) 54-68.

[9] S. Tandrup Schmidt, C. Foged, K.S. Korsholm, T. Rades, D. Christensen, Liposome-Based Adjuvants for Subunit Vaccines: Formulation Strategies for Subunit Antigens and Immunostimulators, Pharmaceutics 8(1) (2016) 7.

[10] A. Akinc, A. Zumbuehl, M. Goldberg, E.S. Leshchiner, V. Busini, N. Hossain, S.A. Bacallado, D.N. Nguyen, J. Fuller, R. Alvarez, A combinatorial library of lipid-like materials for delivery of RNAi therapeutics, Nature Biotechnology 26(5) (2008) 561-569.

[11] I. Lostalé-Seijo, J. Montenegro, Synthetic materials at the forefront of gene delivery, Nature Reviews Chemistry 2(10) (2018) 258-277.

[12] T.D. Brown, K.A. Whitehead, S. Mitragotri, Materials for oral delivery of proteins and peptides, Nature Reviews Materials 5(2) (2020) 127-148.

[13] R.M. Krause, N.J. Dimmock, D.M. Morens, Summary of Antibody Workshop: The Role of Humoral Immunity in the Treatment and Prevention of Emerging and Extant Infectious Diseases, Journal of Infectious Diseases 176(3) (1997) 549-559. 
[14] C.C. Bergmann, T.E. Lane, S.A. Stohlman, Coronavirus infection of the central nervous system: host-virus stand-off, Nature Reviews Microbiology 4(2) (2006) 121-132.

[15] E.-C. Shin, P.S. Sung, S.-H. Park, Immune responses and immunopathology in acute and chronic viral hepatitis, Nature Reviews Immunology 16(8) (2016) 509-523.

[16] F. Tang, Y. Quan, Z.T. Xin, J. Wrammert, M.J. Ma, H. Lv, T.B. Wang, H. Yang, J.H. Richardus, W.J.J.o.I. Liu, Lack of Peripheral Memory B Cell Responses in Recovered Patients with Severe Acute Respiratory Syndrome: A Six-Year Follow-Up Study, 186(12) (2011) 7264-7268.

[17] O.-W. Ng, A. Chia, A.T. Tan, R.S. Jadi, H.N. Leong, A. Bertoletti, Y.-J. Tan, Memory T cell responses targeting the SARS coronavirus persist up to 11 years post-infection, Vaccine 34(17) (2016) 2008-2014. [18] H. Shen, A.L. Ackerman, V. Cody, A. Giodini, E.R. Hinson, P. Cresswell, R.L. Edelson, W.M. Saltzman, D.J. Hanlon, Enhanced and prolonged cross-presentation following endosomal escape of exogenous antigens encapsulated in biodegradable nanoparticles, Immunology 117(1) (2006) 78-88.

[19] D. Qiao, L. Liu, Y. Chen, C. Xue, Q. Gao, H.-Q. Mao, K.W. Leong, Y. Chen, Potency of a Scalable Nanoparticulate Subunit Vaccine, Nano Letters 18(5) (2018) 3007-3016.

[20] Tung Thanh Le, Zacharias Andreadakis, Arun Kumar, Raúl Gómez Román, Stig Tollefsen, M.S. \&, S. Mayhew, The COVID-19 vaccine development landscape, Nature Reviews Drug Discovery (2020). [21] L. Du, Y. He, S. Jiang, B. Zheng, Development of subunit vaccines against severe acute respiratory syndrome, Drugs of Today 44(1) (2008) 63-73.

[22] C. Drosten, S. Günther, W. Preiser, S. van der Werf, H.-R. Brodt, S. Becker, H. Rabenau, M. Panning, L. Kolesnikova, R.A.M. Fouchier, A. Berger, A.-M. Burguière, J. Cinatl, M. Eickmann, N. Escriou, K.

Grywna, S. Kramme, J.-C. Manuguerra, S. Müller, V. Rickerts, M. Stürmer, S. Vieth, H.-D. Klenk, A.D.M.E. Osterhaus, H. Schmitz, H.W. Doerr, Identification of a Novel Coronavirus in Patients with Severe Acute Respiratory Syndrome, New England Journal of Medicine 348(20) (2003) 1967-1976.

[23] A.M. Zaki, S. van Boheemen, T.M. Bestebroer, A.D.M.E. Osterhaus, R.A.M. Fouchier, Isolation of a Novel Coronavirus from a Man with Pneumonia in Saudi Arabia, New England Journal of Medicine 367(19) (2012) 1814-1820.

[24] W. Li, J. Sui, I.C. Huang, J.H. Kuhn, S.R. Radoshitzky, W.A. Marasco, H. Choe, M. Farzan, The S proteins of human coronavirus NL63 and severe acute respiratory syndrome coronavirus bind overlapping regions of ACE2, Virology 367(2) (2007) 367-374.

[25] A.C. Walls, Y.-J. Park, M.A. Tortorici, A. Wall, A.T. McGuire, D. Veesler, Structure, Function, and Antigenicity of the SARS-CoV-2 Spike Glycoprotein, Cell (2020) S0092-8674(20)30262-2.

[26] N. Wang, J. Shang, S. Jiang, L. Du, Subunit Vaccines Against Emerging Pathogenic Human Coronaviruses, Frontiers in microbiology 11 (2020) 298-298.

[27] L. Du, Y. He, Y. Zhou, S. Liu, B.-J. Zheng, S. Jiang, The spike protein of SARS-CoV - a target for vaccine and therapeutic development, Nature Reviews Microbiology 7(3) (2009) 226-236.

[28] S.G. Reed, M.T. Orr, C.B. Fox, Key roles of adjuvants in modern vaccines, Nature Medicine 19(12) (2013) 1597-1608.

[29] R. Channappanavar, J. Zhao, S. Perlman, T cell-mediated immune response to respiratory coronaviruses, Immunologic research 59(1-3) (2014) 118-128.

[30] W. Sungnak, N. Huang, C. Bécavin, M. Berg, R. Queen, M. Litvinukova, C. Talavera-López, H. Maatz, D. Reichart, F. Sampaziotis, K.B. Worlock, M. Yoshida, J.L. Barnes, N.E. Banovich, P. Barbry, A. Brazma, J. Collin, T.J. Desai, T.E. Duong, O. Eickelberg, C. Falk, M. Farzan, I. Glass, R.K. Gupta, M. Haniffa, P. Horvath, N. Hubner, D. Hung, N. Kaminski, M. Krasnow, J.A. Kropski, M. Kuhnemund, M. Lako, H. Lee, S. Leroy, S. Linnarson, J. Lundeberg, K.B. Meyer, Z. Miao, A.V. Misharin, M.C. Nawijn, M.Z. Nikolic, M. 
Noseda, J. Ordovas-Montanes, G.Y. Oudit, D. Pe'er, J. Powell, S. Quake, J. Rajagopal, P.R. Tata, E.L. Rawlins, A. Regev, P.A. Reyfman, O. Rozenblatt-Rosen, K. Saeb-Parsy, C. Samakovlis, H.B. Schiller, J.L. Schultze, M.A. Seibold, C.E. Seidman, J.G. Seidman, A.K. Shalek, D. Shepherd, J. Spence, A. Spira, X. Sun, S.A. Teichmann, F.J. Theis, A.M. Tsankov, L. Vallier, M. van den Berge, J. Whitsett, R. Xavier, Y. Xu, L.-E. Zaragosi, D. Zerti, H. Zhang, K. Zhang, M. Rojas, F. Figueiredo, H.C.A.L.B. Network, SARS-CoV-2 entry factors are highly expressed in nasal epithelial cells together with innate immune genes, Nature Medicine 26(5) (2020) 681-687.

[31] A. Wang, T. Yang, W. Fan, Y. Yang, Q. Zhu, S. Guo, C. Zhu, Y. Yuan, T. Zhang, Y. Gan, Protein Corona Liposomes Achieve Efficient Oral Insulin Delivery by Overcoming Mucus and Epithelial Barriers, Advanced Healthcare Materials 8(12) (2019) 1801123.

[32] L. Yuan, L. Wu, J. Chen, Q. Wu, S. Hu, Paclitaxel acts as an adjuvant to promote both Th1 and Th2 immune responses induced by ovalbumin in mice, Vaccine 28(27) (2010) 4402-4410. 